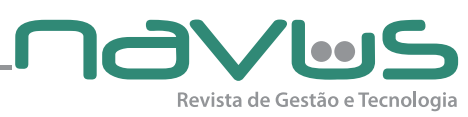

\title{
A model of success: (creation of a) culture of friendly innovation generation for german SMES
}

Gordon Lemme

\section{ABSTRACT}

In the course of the demographic development in Germany, the ratio of elderly workers grows compared to the share of young qualified employees. As a consequence, professional shortages are an increasingly growing problem. Hence, it is more and more important, especially for German small and medium-sized enterprises (SMEs), to develop strategies in order to handle this demographic change. Skilled employees have a major impact on the development of innovations particularly in SMEs. Their closely customercorporate relationship in combination with a high number of SMEs in Germany forces them to be innovative in order to stand out from the crowd. Due to identified deficits regarding an appropriate human resources management as well as a structured innovation process management within SMEs, the German Federal Ministry of Labour and Social Affairs is funding several research projects to support SMEs by using a set of manifold instruments with the aim to solve the stated problems. The presented research project, called generIK (setting up generation equitable innovation cultures within SMEs), aims to sensitize SMEs and business leaders to build up such a generation friendly innovation culture as part of a holistic corporate culture. Instead of the age of an employee it is his/her personal attitude to the work which decisively influences the engagement to improve products, what finally can lead to the realization of innovations. As further research results, the scientists developed several analysis-methods among them an instrument to conduct a company-specific self-validation for SMEs. To strengthen the market position of SMEs in times of the demographic change which should be accompanied by a rise of employee and customer satisfaction, the output of our project has to be disseminated to the SMEs and especially to the business leaders.

Keywords: Innovation. Management. Demographic change. Elderly worker.

${ }^{1}$ Dipl.-Medieninf. Dresden University of Technology - gordon.lemme@tu-dresden.de 


\section{INTRODUCTION}

According Günther Verheugen, formerly member of the European Commission, SMEs are the engine of the European economy. They contribute substantially to the employment creation, they promote the entrepreneurial spirit, and they are crucial for the innovation ability of the business sector. Hence, they have a decisive influence on the development of competitiveness and employment within the European Union (EUROPÄISCHE KOMMISION, 2013).

Not solely in Germany but right across Europe, SMEs have an enormous economic power. There are about 23 million small and medium-sized enterprises in the extended European Union, which represent with a ratio of $99 \%$ the majority of all European enterprises (EUROPÄISCHE KOMMISION, 2013). In the year 2010 the proportion of SMEs in Germany was approximately 99.5\% (INSTITUT FÜR MITTELSTANDSFORSCHUNG, 2013), in which $60 \%$ of the employees subject to social insurance contribution has been engaged (BUNDESMINISTERIUM FÜR WIRTSCHAFT UND TECHNOLOGIE, 2012). Furthermore, five of six German trainees are educated in small and medium-sized enterprises. This means that 1.3 million of the 1.6 million training places in Germany are provided by SMEs (BUNDESMINISTERIUM FÜR WIRTSCHAFT UND TECHNOLOGIE, 2012).

The characteristic advantages of small and medium-sized enterprises predetermine them to create innovations permanently. At the organization level, among others the flat enterprise hierarchy and a less pronounced formalism are important properties. This reduces problems of coordination and in general decision-making procedures take place much faster than in large-scale companies (RAMMER; SPIELKAMP, 2006). In addition, a high flexibility arises from short, direct information paths at all business levels. The mainly informal flow of information through face-to-face communication between the employees also accelerates the dissemination of information and prevents misunderstandings and misinterpretations. These SMEs-specific strengths proceed at the process level as the production-related flexibility, the fundamental and more pragmatically development activities, or the strong customer-focused and result-oriented way of working. As a consequence SMEs are in fact favored in the process of creating innovations in comparison to large-scale companies. Moreover, decisions are often accelerated by a professionally motivated business owner, which is involved in the process of innovation (PROGNOS AG, 2006).

The innovation activities in German enterprises are collected through various studies. Rammer and Hünermund showed that Germany has a highly innovative national economy in comparison to other European countries (RAMMER; HÜNERMUND, 2013). In no other country of the European Union is the ratio of innovative enterprises is higher as in Germany, a result of the orientation of German SMEs to innovate. Moreover, this forms a decisive competitive advantage at the international level, which is necessary to consolidate in future.

Even if German SMEs are highly innovation oriented, in many cases their corporate structure, the ongoing business processes as well as the corporate culture are not yet best adapted to an effective development and market introduction of innovations. Moreover, human and financial resources of SMEs are generally limited. The presented check "Innovation" aims to support SMEs to improve their innovative ability.

With regard to the demographic development in Germany the project generIK, which is funded by the Federal Ministry of Labour and Social Affairs, has the task to encourage small and medium-sized enterprises for a generation equitable culture of innovation. SMEs shall be enabled to keep their competitive advantage in the national and international comparison. Therefore, six innovative model enterprises are supporting the project consortium to develop and to try out a tool set focused on adjusting the consolidation of the high innovative ability and the consequences of demographic development in Germany. Besides the raise of a fundamental awareness to the upcoming challenges due to the demographic change, the aim of our study is the compensation of SME-specific weaknesses with respect to the innovation process.

The selection of those model enterprises is based on the established definition of SMEs, which is uniform in the whole European Union. According to this definition, a SME may not engage more than 250 employees. Furthermore the annual turnover may not be any more than 50 million Euros and the balance sheet at most 43 million Euros once a year. Independently of the other parameters, enterprises which are more than $25 \%$ owned by another enterprise may not be classified as SMEs.

As an additional selection criterion in the context of the project generIK, the model enterprises had successfully placed at least one innovation on the market in the previous three years. The analysis of the age distribution as well as the process design of innovation were part of the our study and were carried out with the help of project specific instruments. These instruments will be described later and illustrated exemplarily. 


\subsection{THE EMPLOYMENT OF ELDERLY PEOPLE IN GERMANY}

In Germany the employment of elderly people is closely connected with the demographic development. This so called demographic change is indicated by an increasing proportion of the elderly population over the total population. Whereas in 1990 the quota of the age category "over-65" was about 15\% of the total population, in 2011 it has been increasing up to $21 \%$. This is the highest ratio in Europe (STATISTISCHES BUNDESAMT, 2012). This development is caused by the continuing low birth rate which is already since decades fairly under the replacement level and a rise of the life expectancy (STATISTISCHES BUNDESAMT, 2012). In addition the health satisfaction of the elderly increased as a result of an extensively developed health system in Germany. As a further influencing variable the birth cohorts between 1955 and 1965 are numerically strong due to a high birth rate. Being described as 'baby boomers' this generation is now considered as a growing ratio of elderly professional staff and will strongly contribute a further increase of the age category over-65 in the coming years.

Hence, at the German labour market is increasingly more elderly professional staff available. In addition, in the year 2007 the German Bundestag decided to raise the retirement age of 65 years gradually to 67 years. This means the legal age of retirement shifts, the employees have to work longer. Thus, enterprises need to adapt their working conditions as well as the labour organisation according the needs of the elderly staff. In fact, this requires support and practicable instruments especially for small and medium-sized enterprises.

During the period from 2001 to 2011, the occupation quota of employees subject to social insurance contributions aged between 60 and 65 years more than doubled, with an increase from $15.9 \%$ to $27.5 \%$ in Germany (BUNDESAGENTUR FÜR ARBEIT, 2012). Nevertheless, 72.5\% of this cohort remains without a job requiring social security contributions. Due to the demographic development and the rise of the retirement age in Germany, a further decline and hence an increase in the employment rate can be predicted. To preserve the efficiency of the employees also in the advanced productive age, this requires an early adjustment of entire professional life.

\subsection{THE EMPLOYMENT OF ELDERLY PEOPLE IN EUROPE}

The analysis of the 28 member states of European Union turned out that in the year 2002 merely seven show an employment rate of elderly (between 55-64 years) of more than 50\%. In 2008 this number has doubled. Furthermore the employment rate of elderly people in all European Union member states has increased from $2002(42.0 \%)$ to $49.1 \%$ in the year 2008. Thus, the trend observed throughout Europe is an increasing ratio of elderly workers. This is particularly obvious in countries with fundamentally lower level of labour participation. Portugal, Denmark as well as Iceland (European Union joining candidate) form exceptions where the employment rates of elderly workers have reduced (MÜMKEN; BRUSSIG, 2012). A disproportionate increase in the employment rate was recorded in Slovakia and Bulgaria even if there the employment of elderly has to be classified as rather low. But even in countries with a higher baseline (e.g. Latvia and Estonia), the employment rates of elderly worker could be increased further.

Under consideration of the educational level it stands out that both, in countries with a low employment rate of elderly people (e. g. Germany, France, Spain and Netherlands) as well as in countries with an middle average employment quota of elderly worker (e. g. Hungary and Italy) persons with a higher education degree are more often employed. This tendency can be stated also for countries with a fundamental high employment rate of elderly people, such as Sweden or the United Kingdom. Mümken and Brussig (2012) conclude that the level of qualification is more decisive for the structure of the labour market than the age of the employees. As a consequence, the age of the high qualified working force impacts less the probability of employment than in the case of low-skilled workers.

Due to this correlation the age structure analysis instrument of the generIK project consider also the training days for the employees. This was an important starting-point for the sensitization of the management; in fact a decrease of training days could be recorded in all model enterprises with an advancing employee age. This aspect is included in the check "Innovation" and pointed to a central theme: the 'Lifelong Learning' of employees whereby the direct correlation of the know-how of an employee and his innovative capability plays a decisive role.

Following the age structure instrument is outlined in an abridged version with the most important elements. It was taken care that the applicability for SMEs and the daily work routine to the management remains ensured. A simple template which is to complete by the company allows to analyze the current employment situation as shown in table 1 but also to forecast its development in the coming years. The tool had to be extended by the scientists which used in addition another specific age structure analysis 
instrument. This instrument, shown in figure 1, represents the age distribution of the enterprise using the recorded information as a reference curve within 10 years.

\begin{tabular}{|c|c|c|c|c|c|c|}
\hline $\begin{array}{c}\text { name of } \\
\text { employee }\end{array}$ & birthday & $\begin{array}{c}\text { Formal educational } \\
\text { qualification }\end{array}$ & job title & $\begin{array}{c}\text { Service with } \\
\text { the company }\end{array}$ & Field of activity & $\begin{array}{c}\text { Number of } \\
\text { training days }\end{array}$ \\
\hline employee 1 & 07.03 .1957 & $\begin{array}{c}\text { graduate engineer in } \\
\text { mechanical engineering }\end{array}$ & business leader & 32 years & management & 2 \\
\hline employee 2 & 27.06 .1987 & craftsman & precision engineer & 4 years & production & 12 \\
\hline employee ... & 13.11 .1962 & craftsman & CNC-machinist & 17 years & production & 1 \\
\hline employee n & 18.07 .1994 & trainee & $\begin{array}{c}\text { technical drafts- } \\
\text {-woman }\end{array}$ & 1 year & pre-production & 8 \\
\hline
\end{tabular}

Source: the author (2013)

Figure 1 - example of an age analyse diagram for KMU

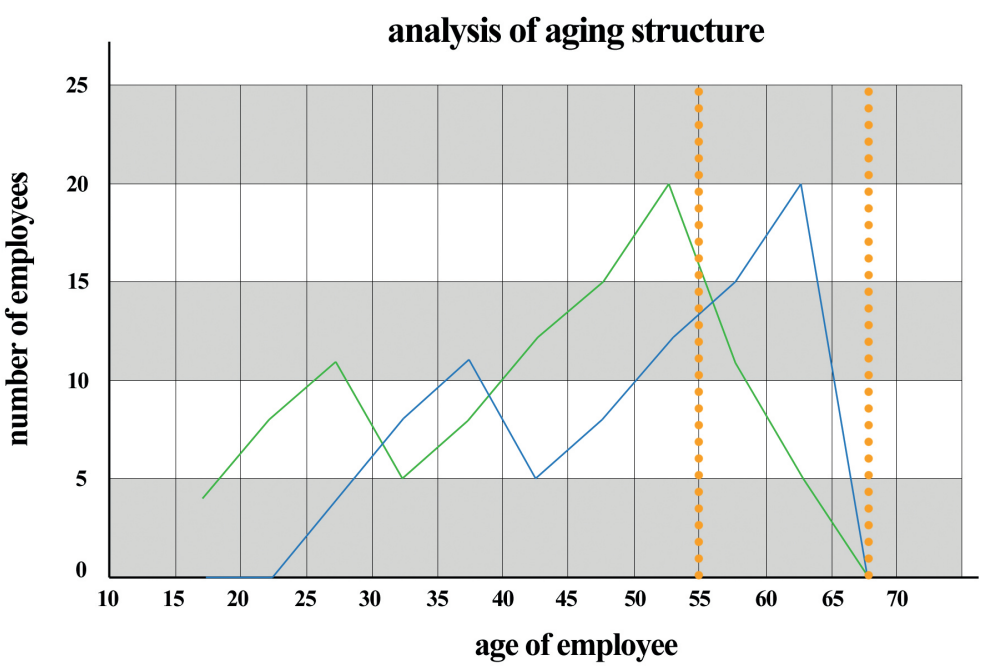

Source: the author (2013)

\section{INNOVATION ACTIVITIES IN SMES}

In the society, politics, and particularly in the economy the term "innovation" is used in a quite inflationary manner. Through this, a uniform understanding of innovation could not be found - neither in scientific nor in the economic sphere. In the context of an extensive literature analysis Franke and Dömötör noticed in 2008 that the business approach and the related studies to explore the success factors refer only to large-scale enterprises (FRANKE; DÖMÖTÖR, 2008). However, the capacity for innovation in SMEs plays a crucial role.

It requires an enterprise internal and therefore individual definition to clarify the understanding of innovation for SMEs. In general the following four criteria were used in the context of the project to describe the term 'innovation':

1. Innovation is the target-oriented development and implementation of new value-added solutions for products, services, and processes.

2. Those developed solutions are quite different from the previous conditions.

3. "New" is the solution from the perspective of the respective enterprise and/or its customers.

4. The generation of an idea is not yet an innovation. An idea becomes an innovation in the case it is used or commercialised by enterprise and/or their customer.

To obtain a enterprise-specific definition, we used the method of the semantic differential in a model 
enterprise.

The method of the semantic differential was developed as polarity profile a by Osgood (1952) and introduced by Hofstätter (1959) in the German speaking area. This tool serves the analysis and measuring of the semantic meaning of objects or terms based on associations. A semantic differential consists of a noncommittal number of bipolar rating scales, whose ends are described by adjectives (BORTZ; DÖRING, 2006). For the determination of the innovation term, the predefined semantic differential by Beelitz von Busse and Schulz was used, which is proved in a number of examinations (BEELITZ VON BUSSE; SCHULZ, 2000). Due to its pre-formulated and validated couples of adjectives are SMEs able to use this tool in the context of an interview without a broader basic knowledge. The examination made anonymous was carried out with all employees in one of the model enterprises $(n=12)$. The following evaluation was carried out solely in a descriptive form with statistical characteristic values (arithmetical mean, range) due to the low number of interviewed employees. Through a graphical processing of the examination parameters following spans referring to the term 'innovation' were generated in the model enterprise.

Figure 2 - semantic differential for one model SME

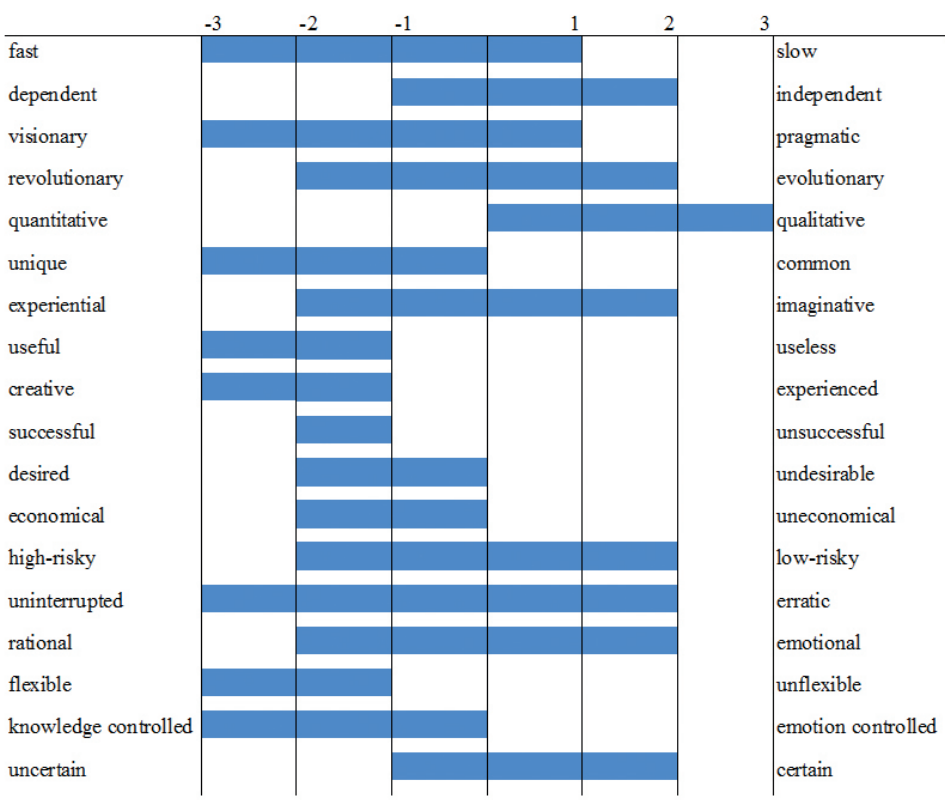

Source: the author (2013)

In figure 2 it is considerably visible that the employees in the model enterprise have miscellaneous associations with the term "innovation". To generate a uniform definition, the adjectives with the smallest/ lowest range (width <=2) and an arithmetical mean higher 1.6 or smaller -1.6 were used. For the shown model enterprise, the adjectives to be used were "useful", "creative" and "flexible". Furthermore, tradespecific terms were integrated into the definition based on a consultation with the enterprise management. This method led to the following individual definition of the term "innovation" defined by one of the model enterprises.

"Innovation is the target-oriented development and flexible implementation of a qualitatively new as well as useful technical, economic, organizational, and/or social idea to the value creating problem solution for new or already known needs. It is noticeably different in comparison to any enterprise external and/or in-house conditions. The innovation results from a creative idea and its implementation as an useful product or process. It aims to place successfully the new succeed on the market with increasing an enterprise and/ or customer benefit by a useful added value."

With the help of the semantic differential the basis for the description of an innovation process can be considered as created. Furthermore this uniform definition promotes the understanding as well as the communication in connection with the innovation process. 


\section{INNOVATION PROCESS MODEL IN SMES}

For the modelling of the innovation process in the selected model enterprises, the generIK project orientates on a six-phase-model. It should be mentioned that not all phases have to be available within a single enterprise. E.g. the launch of a product can be dropped for a supplier if the customer has concluded an exclusive contract with the enterprise and functions therefore as an only buyer. Product tests and/or market analyses (phase product/market test) can as well be allocated to experts due to the missing competence of the staff in the SME. Merely the first two phases of the used study design had to be found in one of the model enterprises within the project. Due to the economical branches of the studied enterprises, only the phases of the idea generation and development of the concept within the innovation process were available for an analysis.

Aim of the innovation process modelling is the representation of the process of innovation in the specific enterprise. It requires an instrument to illustrate the process because in many cases we observed that the innovation process occurs in an unstructured way. Through such an illustrated representation of the internal process we can detect problems in the information flow as well as interface problems in SMEs.

Two instruments were used for the process of innovation modelling in the context of the generIKproject. The analysed enterprises compiled retrospectively a process of innovation and linked the involved employees with the pre-formulated phases of the innovation process. An example is shown in figure 3.

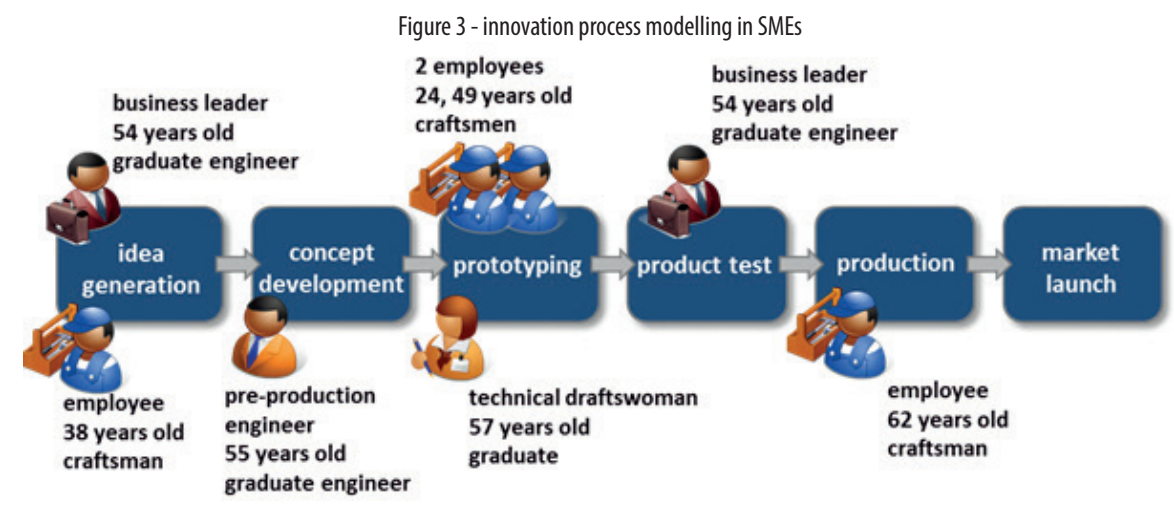

Source: the author (2013)

In a further step the scientists converted a model of an in-house innovation process into the business process model and notation (BPMN) language. The individual processing steps could be discussed and completed partly with the help of a group discussion presented by a moderator within the model enterprise. As a result of this discussion problems in the information flow and important innovation drivers could be exposed for the enterprise. Moreover, in the context of the complete project it turned out that the age does not have influence on the innovative capability of the employees. This fact coincides with an interview carried out under German demographic experts. Furthermore, these consider only the prevailing deficit hypothesis or age stereotypes in SMEs as reason for the lacking participation for elderly in the innovation process with a mentioning of $66 \%(n=12)$. The demographic experts certify SMEs the need for sensitization of this at the integration of elderly employees. It is necessary to offer innovation help for the enterprises with the developed check.

\section{INNOVATION CULTURE IN GERMAN SMES}

In a last step the innovation culture of the corporate enterprises has been studied in the context of the project. To this the employees who are involved in the process of innovation in the model enterprises were characterized. They were interviewed by experts and judged by other employees partly. The project consortium tried to orientate at the promotor-modell, which was propagated by Eberhard Witt in a first form in 1973 and was enlarged by Jürgen Hauschildt and Hans Georg Gemünden later on. The term 'promoter' describe people who have a growing interest in the execution or the success of an innovation process. They 
accompany the innovation plan and influence the process directly. The different types of promoters will be described and interpreted in their specific functions for SMEs. In addition, we extended the existing models of promoters by a further one: regarding the close customer-corporate relationship of SMEs, customers have also an enhanced interest in the success of an innovation project.

\subsection{POWER PROMOTORS}

Generally in SMEs power promoters are close connected with the enterprise, they often work for a long time in this company or even established it. Thus, the power promoter is often represented by the business leader in SMEs. The goal of the company and the method to reach it, is based on his strategic thinking. Especially in small enterprises power promoters often have high level of technical knowledge and are also integrated in the production process.

\subsection{PROFESSION PROMOTERS}

Profession promoters have an enterprise-wide appreciation due to their broad expertise. They know alternative procedures as well as the limitations of products or processes. Profession promoters are the problem solvers and particularly in SMEs directly involved in the realization of an innovation. They are not subject to any temporal enterprise membership and cannot be assigned to any specific age group.

\subsection{PROCESS PROMOTORS}

In general process promoters have high organization skills. In SMEs they can be found mostly in combination with other promoters. They are characterized by having a considerable experience of internal processes and procedures. Due to the already mentioned flat organizational structure in SMEs as well as the limited size of the enterprise, mainly power promoters have the additional role to be also process promoter. They seek to avoid spot solutions and maintain a internal corporate network to every employee. In the course of the innovation process this kind of promoter has the ability to decompose processes into subprocesses. In this way he is able to derive a procedure from an idea. Process promoters often stay in the enterprise for a long time and therefore, they can be assigned to a rather elderly age group.

\subsection{RELATIONSHIP PROMOTERS}

In general relationship promoters remove innovation barriers and regulate formal aspects in the process of innovation. They have an enterprise-wide network of project and partner companies. Relationship promoters cannot be assigned to any age group and do not have to be employees of the enterprise either. In the proper sense, there are rarely relationship promoters in SMEs. For companies of this category the support of transfer professionals which have the characteristics and tasks of relationship promoters has as very positive influence as shown in other empirical studies (KRAUSE-JÜTTLER; BAU, 2012).

\subsection{CUSTOMER}

Basically the customer does not form any promoter in the proper meaning. However, the studies of the innovation process in the model enterprises clearly showed that there is a very close relationship between innovator and customer. On one hand this situation results from the fact that SMEs are able to react to customer requests in a flexible way; on the other hand it is owing to the already specified weaknesses of SMEs. Important to consider are the general low financial resources of SMEs and the financial risks of individual manufacturing. From the close relation between customer and company arises a win-win situation in which the customer gets the product according his individual ideas. Therefore, the customer represents an important element in the analysis of promoters. With the inclusion of his customers the innovator has already a purchaser of the new product or developed process, whereby the financial risks of the company decrease.

In the context of the project in all model enterprises the promoters have come to light in different expression and the customer act as employer as well as an activator for innovations. The constellation with the customer as an innovation trigger was disproportionately common in all considered model enterprises. An individual customer-specific result can be obtained and the risk of a failure or a missing market can be reduced by this direct involvement in the process of innovation. 
Furthermore, it was found by the scientists that especially in small enterprises a match of several promoter qualities in one person can be observed. This fact is caused by the characteristics of SMEs; and it contributes to accelerate the innovation process. In contrast to this finding, the achieved degree of a produced innovation is assessed as still rather low, because rather less creative provider of ideas and discussion partners are involved in the innovation process in SMEs. Nevertheless the promoters constitute an elementary component in German SMEs and influence the culture of innovation.

\section{CREATION OF A GENERATION FRIENDLY INNOVATION CULTURE}

With the help of the explained instruments it is possible to analyze SMEs in terms of their innovation culture. The age structure analysis serves the representation of the current state as well as a forecast of the enterprise situations within the next years.

Based on the semantic differential SMEs can achieve a basic clarification of the term innovation to develop an enterprise uniform and specific understanding of innovation. By targeted interviews and group discussions the structure of an innovation process can be modelled and flows of information are outlined on basis of a uniform understanding of innovation. Subsequently with the assignment of promoters the process of innovation can be completed to outline such an ideal enterprise-specific process of innovation.

By the developed check "Innovation" the management in SMEs shall be sensitized to the integration of all especially elderly employees using the process of innovation of their own. For this purpose a SMEssuitable instrument was developed, which presents itself as a component of the Initiative Neue Qualtität der Arbeit (INQA - Initiative New Quality Work) and can be independently filled by the business leader. The check "Innovation" is divided into five chapters and helps SMEs to find and eliminate weaknesses in their process of innovation. To develop new ideas of where innovation can occur, the check included the creation of conditions or structures as well as an open atmosphere of work. In further main fields the check "Innovation" examines the available competences of employees as well as the customer as a partner and information source in the innovation process. In another chapter the operational organization is analyzed to be able to take up innovative suggestions. The section following on this deals explicitly with the integration of all age groups into the process of innovation. The strengths of every age are worked out for the process of innovation and represented using examples in the check. The last chapter examines the efficiency and quality of the innovation process and offers possibilities of influencing these positively. Furthermore the check includes a number of action recommendations to present the business leader first suitable measures for the improvement of the own innovation process.

\section{UM MODELO DE SUCESSO : (CRIAÇÃO DE UMA ) CULTURA DE GERAÇÃO VOLTADA A INOVAÇÃO PARA AS SMES ALEMÃS}

\section{RESUMO}

No processo de desenvolvimento demográfico na Alemanha, a proporção de trabalhadores idosos cresce em comparação com a percentagem de novos trabalhadores qualificados. Como consequência, a escassez de profissionais é um problema cada vez mais frequente. Por isso, é fundamental, especialmente para as pequenas e médias empresas alemãs (SMEs), desenvolverem estratégias para lidar com essa mudança demográfica. Trabalhadores qualificados têm um grande impacto sobre o desenvolvimento de inovações, particularmente nas (SMEs). A estreita relação cliente - empresa, associada a um elevado número de (SMEs) na Alemanha obriga-os a serem inovadores, a fim de se destacarem da multidão. Devido aos déficits identificados sobre uma gestão de recursos humanos adequados, bem como a gestão do processo de inovação estruturado dentro das (SMEs), o Ministério do Trabalho e dos Assuntos Sociais está financiando vários projetos de investigação de apoio às (SMEs) através de um conjunto de vários instrumentos com o objetivo de resolver os problemas indicados . 0 projeto de pesquisa apresentado, chamado Generik (criação de geração de culturas de inovação equitativas dentro das (SMEs), tem como objetivo sensibilizar as (SMEs), e líderes empresariais para construírem uma cultura de geração voltada à inovação como parte de uma cultura organizacional holística. Em vez da idade de um empregado, é o seu / sua atitude pessoal com o trabalho que influencia decisivamente o compromisso de melhorar os produtos, o que finalmente pode levar à realização de inovações.Como resultados da pesquisa, os cientistas desenvolveram vários métodos 
de análise entre eles um instrumento para realizar uma auto validação específica da empresa para as (SMEs). Para fortalecer a posição das (SMEs) no mercado em tempos de mudança demográfica, que deve ser acompanhada pelo aumento do funcionário e satisfação do cliente no mercado, o resultado do nosso projeto tem que ser divulgado para as (SMEs) e, especialmente para os líderes empresariais.

Palavras-chave: Inovação. Gestão. Mudanças demográficas. Trabalhador idoso.

\section{REFERENCES}

BEELITZ VON BUSSE, N.; SCHULZ, K. P. Merkmale erfolgreicher Innovationsprozesse.

Befragungsergebnisse aus fünf Jahren: Chemnitz, 2000.

BORTZ, J.; DÖRING, N. Forschungsmethoden und Evaluation für Human- und Sozialwissenschaftler. Berlin: Heidelberg,2006.

BUNDESAGENTUR FÜR ARBEIT. Arbeitsmarktberichterstattung: Der Arbeitsmarkt in Deutschland, Ältere am Arbeitsmarkt. Nürnberg: Bundesagentur für Arbeit, 2012.

BUNDESMINISTERIUM FÜR WIRTSCHAFT UND TECHNOLOGIE. Wirtschaftsmotor Mittelstand - Zahlen und Fakten zu den deutschen KMU. [2012]. Available in: <http://www.bmwi.de/BMWi/Redaktion/ $\mathrm{PDF} / \mathrm{W} /$ wirtschaftsmotor-mittelstand-zahlen-und-fakten-zu-den-deutschen kmu,property=pdf,bereich=bm wi2012,sprache=de,rwb=true.pdf> Access: 26 Aug. 2013.

EUROPÄISCHE KOMMISION. Die neue KMU-Definition: Benutzerhandbuch und Mustererklärung. [2013]. Available in: <http://ec.europa.eu/enterprise/policies/sme/files/sme_definition/sme_user_guide_de.pdf> Access: 12 Apr. 2013.

FRANKE, N.; DÖMÖTÖR, R. Innovativität von kleinen und mittleren Unternehmen (KMU): Gestaltungsvariablen, Konfigurationen und Erfolgswirkung. In: FRANK, H; NEUBAUER, H.; RÖSSL, D. Beitrag zur Betriebswirtschaftslehre der Klein- und Mittelbetriebe. Berlin: Duncker \& Humbolt GmbH, 2008. p. 139-158.

HOFSTÄTTER, P. Zur Problematik der Profilmethode. Diagnostica, Göttingen, n. 5, p. 19-25, 1959.

INSTITUT FÜR MITTELSTANDSFORSCHUNG. Unternehmensbestand. [2013]. Available in: <http://www. ifm-bonn.org/statistiken/unternehmensbestand/\#accordion=0\&tab=0> Access: 26 Aug. 2013.

KRAUSE-JÜTTLER, G.; BAU, M. Ergebnisse. In: SCHMAUDER, M. (Org.). Transferszenarien: Bedingungen erfolgreicher Kooperationsbeziehungen zwischen Wissenschaft und Wirtschaft in innovationsprozessen. Dresden: Technische Universität Dresden, 2012. p. 24-35.

MÜMKEN, S.; BRUSSIG, M. Altersübergangsreport. [2012]. Available in: <http://www.iaq.uni-due.de/auemreport/>. Acces: 14 Oct. 2013.

OSGOOD, C. The nature of measurement of meaning. Psychological Bulletin, Illinois, v. 49, n. 3, p. 197-237, May 1952.

PROGNOS AG. Zukunft Handwerk: Der Beitrag des Handwerks im Innovationsprozess. Berlin: Prognos, 2006.

RAMMER, C.; HÜNERMUND, P. Innovationsverhalten der Unternehmen in Deutschland 2011. Berlin: ZEW, 2013.

RAMMER, C.; SPIELKAMP, C.(2006). FuE-Verhalten von klein und Mittelunternehmen. In: LEGLER, H.; GRENZMANN, C. (Org.). FuE-Aktivitãten der deutschen Wirtschat, Analysen auf der Basis von FuE-Erhebungen, Materialien aus der Wissenschaftsstatistik. Reihentitel: Materialien zur Wissenschaftsstatistik, 2006. p. 83-102.

STATISTISCHES BUNDESAMT. Alter im Wandel. Nürnberg: Statistisches Bundesamt, 2012. 